The issue of syringes was recorded by the pharmacy staff so that patients could subsequently obtain further annual supplies, which were recorded on a central register in the hospital pharmacy. Those patients unable to reuse the syringes as recommended were encouraged to purchase further supplies from retail chemists to supplement the annual hospital issues. One year after the changeover began the patients were sent a questionnaire. Their responses were coded and the statistical analysis performed on an ICL 2970 computer with the SPSS package.

\section{Patient details}

\begin{tabular}{|c|c|c|c|c|}
\hline & All patients & $\begin{array}{c}\text { Patients } \\
\text { changing from } \\
\text { glass to } \\
\text { plastic syringes }\end{array}$ & $\begin{array}{l}\text { Patients } \\
\text { already using } \\
\text { plastic } \\
\text { syringes }\end{array}$ & $\begin{array}{c}\text { Patients } \\
\text { continuing } \\
\text { to use glass } \\
\text { syringes }\end{array}$ \\
\hline No $(\%)$ & 630 & $451(71 \cdot 6)$ & $151(24 \cdot 0)$ & $28(4 \cdot 4)$ \\
\hline Mean age (years) (range) & $49(15-91)$ & $50(15.91)$ & $47(16-86)$ & 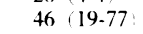 \\
\hline $\begin{array}{l}\text { Mean duration of diabetes } \\
\text { (years) (range) }\end{array}$ & $15(1-55)$ & $16(1-54)$ & $11(1-55)$ & $20(1-48)$ \\
\hline Male & $340) 54$ & $254(56)$ & $66(44)$ & $20 \star(70)$ \\
\hline Female & $290(46)$ & $197(44)$ & $85(56)$ & $8(30)$ \\
\hline \multicolumn{5}{|l|}{ No $\%$ of injections day } \\
\hline 1 & $203(32)$ & 150 & $45(30)$ & $8 \quad 28 \cdot 5)$ \\
\hline 2 & $424(67)$ & 30066 & $104(69)$ & $20(71 \cdot 5$ \\
\hline 3 & 3 & 1 & 2 & \\
\hline
\end{tabular}

* Significantly more men in this group compared with other groups $(\mathbf{p}=0 \cdot 006)$

A total of 865 patients were circulated and $630(72 \%)$ replied. Some $28(4 \%)$ had continued to use glass syringes, $151(24 \%)$ had used plastic syringes before the changeover, and $451(72 \%)$ had chosen plastic syringes for the first time; 548 $(87 \%)$ thought that administration of insulin was easier with U100 insulin (table) Glass syringes lasted a mean of 10 months, equivalent to an annual usage of $1 \cdot 21$ syringes. The needles used with them lasted a mean of $31 \cdot 8$ injections (steel) and 9.9 injections (disposable). Some $406(90 \%)$ patients using plastic syringes preferred them and used them for an average of 14.2 injections. No patient reported infection at the injection site. The most common reasons for discarding svringes were: blunting of the needle; bending of the needle; fading of markings; simple preference; hospital instructions; and hygiene.

\section{Comment}

This seems to be the largest reported survey of use of insulin syringes, 'and the high response rate of $72 \%$ is sufficient for valid statistical analysis. We confirm the feasibility and safety of multiple reuse of plastic syringes. The number of glass syringes used annually $(1 \cdot 21)$ was similar to that reported in another large study $(1 \cdot 72)$.

Current district costs are $£ 6.67$ for a glass syringe and non-disposable needle, compared with $9 \cdot 5 \mathrm{p}$ for a Becton-Dickinson plastic syringe. This gives an annual cost for patients having twice daily injections of $£ 12.91$ with glass syringes and $£ 4.72$ with plastic syringes and for patients having once daily injections $£ 10 \cdot 49$ and $£ 2 \cdot 36$, respectively. By reusing plastic syringes a calculated minimum saving of $£ 7000$ a year has been made in the Southampton district, not including savings from not providing spare glass syringes, carrying cases, industrial spirit, and cotton wool. Reuse of plastic syringes as described could provide savings of over $£ 0.5$ million a year for the United Kingdom as a whole.

Issuing plastic syringes on the drug tariff through a hospital pharmacy could ensure the safe and economical reuse of syringes. There is no sound basis for continuing to advise single use of plastic insulin syringes.

1 Strathclyde Diabetic Group. Disposable or non-disposable syringes and needles for diabetics? $\mathrm{Br}$ Med F 1983;286:369-70.

2 Collins BJ, Richardson SG, Spence GK, Hunter J. Safetv of reusing disposable plastic insulin syringes. Lancet 1983;i:559-61

3 Mann NP. Johnston DI. Insulin syringe dead-space and diabetic control. Lancet 1981;ii:1120-1.

4 Nie NH, Hull CH, Jenkins JG, Steinbrenner K, Bent DM. Statistical package for the social sciences. 2nd ed. New York: McGraw-Hill, 1975.

5 L.ester E, Woodroffe FJ, Grant AJ. Experience with routine use of plastic syringes. Br Med $\mathcal{J}$ 1984;289:1498-9

(Accepled 25 March 1986)

Department of Diabetes and Endocrinology, Royal South Hants Hospital, Southampton SO9 4PE

A P ALLEN, MA, MRCP, registrar

D J TYMMS, MB, MRCP, senior registrar

B A LEATHERDALE, MD, FRCP, consultant physician

Department of Medicine II, University of Southampton

R S LLOYD, FIMLS, senior chief medical laboratory scientific officer

Correspondence to: Dr Leatherdale.

\section{A new resuscitation apparatus providing $70 \%$ oxygen}

Mouth to mouth ventilation is still the most simple first line resuscitation manoeuvre recommended to the non-anaesthetist. ${ }^{1}$ Any proposed improvement on this technique must be straightforward and foolproof. We report on the performance of a simple apparatus that allows oxygen to be administered during both spontaneous and "expired air powered" ventilation. It also overcomes some of the problems inherent in other methods of resuscitation.

\section{The apparatus}

The apparatus (figure) consists of an Ambu E valve that may be attached to any facemask with a $22 \mathrm{~mm}$ socket or to any endotracheal tube connector of $15 \mathrm{~mm}$ taper. The expiratory port has a $30 \mathrm{~mm}$ taper, which will not connect to any of the other components. A Y piece (Siemens, 6605729 E037E) and a flexible, corrugated $1.5 \mathrm{~m}$ tube (Hudson, 1417) provide a $500 \mathrm{ml}$ oxygen reservoir, with a terminal $22 \mathrm{~mm}$ taper, on to which fits a disposable mouthpiece (Ohmeda, 332555 ). The oxygen connecting tube (Argyle, 8888-230409) fits onto a $15 \mathrm{~mm}$

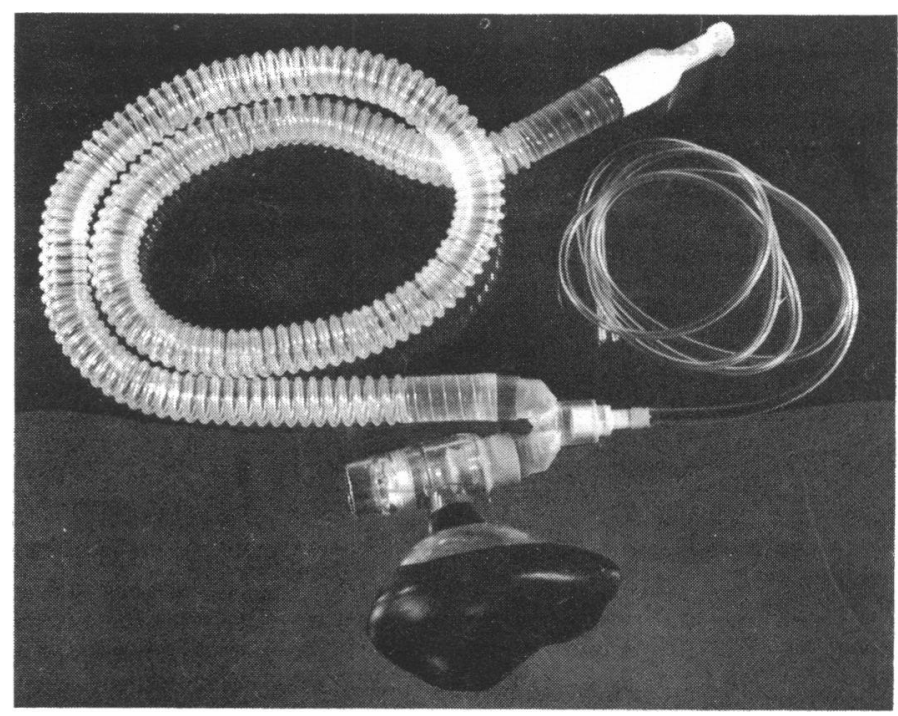

The new resuscitation apparatus.

endotracheal tube connector (Portex, 100/252/080) and is an essential part of the system. It has a high resistance to gas flow, which ensures that satisfactory ventilation is maintained even if it is not connected to (or becomes disconnected from) a supply of oxygen. All joints except those to the Ambu valve and mouthpiece are permanently bonded together by cyanoacrylic adhesive (Loctite 406).

Laboratory evaluation-End tidal carbon dioxide pressure and mean oxygen concentration at the mouth were measured using a Datex Normocap (CD102/02) carbon dioxide and oxygen analyser. Healthy volunteers ventilated spontaneously through the apparatus at 12 breaths per minute, to an end tidal carbon dioxide pressure of $33-40 \mathrm{~mm} \mathrm{Hg}$. With oxygen flows of 2,6 , and $10 \mathrm{l} / \mathrm{min}$ mean oxygen concentrations at the mouth were $34 \cdot 6 \%, 69 \cdot 3 \%$. and $80 \cdot 5 \%$, respectively, after two minutes.

Clinical evaluation-Seventeen patients (10 male and seven female) aged between 3 and 79 were studied during general anaesthesia. They were ventilated using the apparatus with an oxygen inflow of $10 \mathrm{l} / \mathrm{min}$ to an end tidal carbon dioxide pressure of between 30 and $42 \mathrm{~mm} \mathrm{Hg}$. The mean oxygen concentration at the mouth was $80.6 \%$ (range $72-94 \%$ ) after two minutes.

\section{Comment}

The self inflating bag with non-rebreathing valve, facemask, and oropharyngeal airway is traditionally used to provide high oxygen concentrations during resuscitation. Competence in the use of this equipment is, however, low. Unfortunately, mouth to mouth ventilation is aesthetically objectionable and carries the risk of transmission of infection. Use of the oesophageal obturator airway has been shown to be associated with a high incidence of complications. $^{2}$

Mouth to valve to mask ventilation frees both hands to hold the mask and maintain a clear airway. ${ }^{3}$ The technique is readily mastered but does not ensure the delivery of a high concentration of oxygen.

The apparatus described here may be constructed easily using items 
readily available in most hospitals. It provides a high concentration of oxygen with either spontaneous or controlled ventilation and allows the operator to adopt a reasonably comfortable posture, enabling him to hold the mask and giving freedom of vision.

1 Scott DB. Endotracheal intubation: friend or foe. Br Med $\mathcal{F}$ 1986;292:157-8

2 Donen N, Tweed WA, Dashfsky S, Guttormson B. The oesophageal obturator airway: an appraisal. Can Anaesth Soc F 1983;30:194-9.

3 Sivaneswaran N, Lawrence P. Mouth-valve-mask ventilation. Anaesth Intensive Care 1985;13: $336-7$

(Accepled 27 March 1986)

Department of Anaesthesia, Raigmore Hospital, Inverness IV2 3UJ

R JOHNSTON, MB, FFARCS, consultant anaesthetis

J R MACHIN, MB, FFARCS, consultant anaesthetist

A MACNEIL, MB, FFARCS, registrar in anaesthetics

Correspondence to: Dr Machin

\section{Papillitis and hepatitis B}

We report a case of acute hepatitis $B$ virus infection that presented as acute bilateral optic disc papillitis.

\section{Case report}

A 22 year old homosexual man presented with a three week history of deteriorating vision in his right eye, painful eye movements, swollen neck glands, and lassitude. Over the past four years he had had rubella, infectious mononucleosis, genital herpes simplex, non-specific urethritis, gonorrhoea, and
Stored serum samples were subsequently examined for antibodies to the human $T$ lymphotropic virus type III/lymphadenopathy associated virus (HTLV-III/LAV). A serum sample taken in January 1983 was negative, but a sample taken in December 1983 was positive. He admitted to having had several new sexual partners between August and December 1983.

\section{Comment}

Viral disease may be associated with papillitis with or without evidence of intraocular inflammation. ' Papillitis has been reported in association with rubella, ${ }^{2}$ herpes zoster, ${ }^{3}$ chicken pox, mumps, influenza, poliomyelitis, coxsackie virus, ${ }^{\prime}$ and infectious mononucleosis. ${ }^{4}$ One patient reported by Walsh and Hoyt exhibited bilateral optic neuritis after hepatitis B virus infection but suffered persistent disturbance of his colour vision, and the role of hepatitis in the development of his optic neuritis was uncertain. ${ }^{5}$

Our patient had unequivocal clinical and serological evidence of acute hepatitis B infection with an identical time course to the development of papillitis. there were no clinical features of demyelination or raised intracranial pressure.

Lymphadenopathy is common in the early stages of acute hepatitis B infection. As our patient was homosexual it was thought, initially, that his lymphadenopathy might have been unrelated to hepatitis B infection and represented a concurrent persistent lymphadenopathy syndrome secondary to HTLV-III/LAV infection. The subsequent finding of antibodies to HTLV-III/LAV could mean that the patient was immunocompromised at the time of his acute hepatitis $B$ infection and perhaps staged an exaggerated lymph node response because of this. He was, however, negative for HTLVIII/LAV antibodies at presentation, and the lymphadenopathy, ocular features, and immunological abnormalities all cleared after resolution of his acute hepatitis B infection. Although he may have had seronegative HTLVIII/LAV infection, it seems more likely that he acquired HTLV-III/LAV infection when he became sexually active again.

This patient had acute papillitis and lymphadenopathy coincident with serological evidence of acute hepatitis B virus infection. This suggests that hepatitis B virus may be associated with the development of papillitis.

Results of liver function tests

\begin{tabular}{|c|c|c|c|c|c|c|c|c|}
\hline & $25 \mathrm{Jan}$ & $28 \mathrm{Jan}$ & $22 \mathrm{Feb}$ & $20 \mathrm{Apr}$ & $26 \mathrm{Apr}$ & 16 May & 15 June & 4 Aug \\
\hline Anti-HBc & - & & + & & & & & - \\
\hline HBsAg & + & + & + & + & + & + & + & - \\
\hline $\mathrm{HBeAg}$ & + & + & + & + & - & - & - & + \\
\hline Anti-HBe & & & & & - & - & + & - \\
\hline Anti-HBs & & & & & & & & \\
\hline Bilirubin $(\mu \mathrm{mol} / \mathrm{l})($ normal $<19)$ & 7 & & & 10 & 9 & & 6 & \\
\hline Alkaline phosphatase KAU/l (normal $=20-110)$ & 100 & & & 100 & 90 & & 100 & \\
\hline Alanine transferase $(\mathrm{IU} / \mathrm{l})($ normal $<20)$ & 15 & & & 95 & 27 & & 13 & \\
\hline
\end{tabular}

Conversion: SI to traditional units_-Bilirubin: $1 \mu \mathrm{mol} / 1 \approx 0.06 \mathrm{mg} / 100 \mathrm{ml}$

tonsillitis. He had never had jaundice or hepatitis, but three months earlier his regular partner had acute hepatitis B virus infection.

On examination there was generalised lymphadenopathy with firm, nontender nodes $1-2 \mathrm{~cm}$ in diameter. Ocular examination showed visual acuities corrected with glasses of $6 / 18$ (for distance) N5 (for near vision) on the right and $6 / 5 \mathrm{~N} 5$ on the left, his colour vision, pupillary reactions, and extraocular movements being normal. There was a central scotoma in the right field but the left was full, and there were cells in the anterior vitreous bilaterally. Both fundi showed noticeable disc swelling, dilated capillaries, arterial sheathing, haemorrhage in the nerve fibre layer, retinal pigment epithelial change, and macular star formation.

Investigations showed haemoglobin concentration $1.42 \mathrm{~g} / 1$, white cell count $6.6 \times 10^{9} / 1$ with $50 \%$ lymphocytes with atypical lymphocytosis, negative results from Paul Bunnell test, negative syphilis serology, the presence of hepatitis B surface antigen and hepatitis B e antigen (table), and the following viral titres: Epstein Barr virus IgG 1/20, IgM 1/8; cytomegalovirus IgG 1/32, IgM negative; and toxoplasmosis $1 / 16$. These titres remained unchanged at three months. The table gives the results of liver function tests. A computed tomogram of the brain was normal and a cervical node biopsy showed reactive hyperplasia.

The patient remained well without jaundice, and his lassitude, lymphadenopathy, visual function, and serological results improved steadily (table). When examined six months after presentation he had minimal lymphadenopathy and ocular examination was normal.
We thank Professor Dame Sheila Sherlock, Dr D Geraint James, and Dr E Graham for permission to report this patient under their care and for their invaluable help in the preparation of this paper.

1 Miller NR, ed. Optic neuritis. In: Clinical Neuro-ophthalmology. 4th ed. Baltimore: Williams and Wilkins, 1982;1:239-48.

2 Connolly JH, Hutchinson WM, Allen IV, et al. Carotid artery thrombosis, encephalitis, myelitis and optic neuritis, associated with rubella virus infection. Brain 1978;101:495-511.

3 Monroe LD. Optic neuritis in a child with herpes zoster. Ann Ophthalmol 1979;11:405-6.

4 Frey $\mathrm{T}$. Optic neuritis in children. Infectious mononucleosis as an aetiology. Documente Ophthalmologica 1973;34:183-8.

5 Walsh FB, Hoyt WF, eds. Viral hepatitis. In: Clinical Neuro-ophthalmology. 3rd ed. Baltimore: Williams and Wilkins, Vol 2, 1969;2:1375-7.

(Accepted I April 1986

St Thomas's Hospital, London SE1 7EH

C F FARTHING, MB, MRCP, research registrar in genitourinary medicine

R S HOWARD, MB, MRCP, registrar in medical ophthalmology

R N THIN, MD, FRCPED, consultant in genitourinary medicine

Correspondence to: Dr Thin. 